DOI 10.14746/ssp.2018.4.2

\title{
Tinatini DvalishVILI
}

Ilia State University

ORCID: 0000-0001-8822-5404

\section{Interrelation between Cross-Border Cooperation (CBC) and Social Capital: Conceptual Framework}

"All forms of capital represent assets of various kinds yielding streams of benefit."

(Uphoff, 2000)

"Social capital is recognized as 'glue' that holds communities together."

(Tirmizi, 2005)

\begin{abstract}
This article tracks the definitional debates on social capital to demonstrate the many-sided nature of it. Referring to the relational nature of social capital, this paper regards it as an output of cross-border cooperation. The basis of social capital is social interaction, and cross-border cooperation facilitates and reinforces it in equal measure across national borders. Therefore, this article considers cross-border cooperation as one way to generate formal/informal, linking, bonding, bridging, transnational and other varieties of social capital.
\end{abstract}

Key words: social capital, cross-border cooperation (CBC), cross-border settings, social interaction

\section{Introduction}

Cross-border cooperation $(\mathrm{CBC})$ tops the regional policy of the European Union (EU) and refers to the Union's regulated spaces of interaction. The varieties of social capital (SC) are linked to social interactions and trust, which facilitate and/or enhance collective actions. This article strives to unify these two approaches and demonstrates the idea of benefiting from borders. $\mathrm{CBC}$ is observed in terms of transforming borders into the gateways of interaction and increasing mutual understanding between communities. 
CBC is typically discussed as a part of a wider debate over economic development, regional policy, community initiatives, multi-level governance (MLG), and so on. This article supports the understanding of $\mathrm{SC}$ as a by-product of intensive interaction across borders of adjacent neighbors and discusses different types of SC that CBC ensures. This discourse again underlines the contact effect of borders, and contributes to the dismantling of the traditional state-centered concept of borders and their barrier effects.

\section{Setting the scene: definitional debates}

Previously, the dominant economic theories utilized only economic determinants to explain the reasons behind economic development across the world, and socio-cultural variables were not discussed. Later, scientists argued that economic growth was not only a by-product of economic production (physical and human capital), and that socio-cultural factors do indeed matter. This new discourse has triggered the understanding of economic activities as socially constructed phenomena and provoked the dynamic emergence of social capital in economic and political debates. Since the late 1970s, 'social capital' as an interdisciplinary concept enriched the fields of economics, sociology and political science. The term itself implies that there must be social consequences.

Castle (2002) distinguishes the following (self-explanatory) forms of capital: natural, human, human-created and social. As he clarifies, natural capital refers to resources in nature which are used by humans; human capital is linked to the capacity of individuals to satisfy their own needs and those of others; human-created capital is man-made hardware and software brought into existence; and, social capital is linked to groups/ communities' interactions, norms, networks, trust, expectations of reciprocity and information exchange, which are essential for the functioning of the economic and political systems (Castle, 2002, pp. 335-338). Social capital is a vital complement to the concepts of natural, physical, and human capital; it opens up new opportunities, while others restrict. Moreover, Ostrom (2000) explains the following disparities between social and physical capital: 1) "social capital does not wear out with use, but rather with disuse"; 2) it is difficult to see and measure; 3) it is hard to construct through external interventions; 4) national and regional institutions impact the level and type of social capital (Ostrom, 1999, p. 172). 
Lyda Judson Hanifan ${ }^{1}$ remarks: "In the use of the phrase social capital, I make no reference to the usual acceptation of the term capital, except in a figurative sense. I do not refer to real estate, or to personal property, or to cold cash, but rather to that in life which tends to make these tangible substances count for most in the daily lives of people, namely good will, fellowship, mutual sympathy, and social intercourse among a group of people and families who make up a social unit, the rural community" (Hanifan, 1916, p. 130). Hanifan emphasizes that community improvements begin when people get together and accumulate social capital. And, "the more the people do for themselves, the larger will community social capital become, and the greater will be the dividends upon the social investment" (ibid., p. 138).

The origins of the concept of social capital could be traced to Karl Marx (1818-1883), Emile Durkheim (1858-1917), John Dewey (1859-1952), Georg Simmel (1858-1918), and Max Weber (1864-1920), who emphasized the role of culture in economic growth. Later, in the 1960s-80s, the concept was re-developed by the Canadian sociologists (Seely et al., 1956) Jane Jacobs (1961) and Glenn Loury (1977). Since the 1980s, Pierre Bourdieu (1986), James S. Coleman (1988), Robert Putnam (1994), Nan Lin (1999) and Francis Fukuyama (2001) have contributed to the academic debates surrounding the idea that social interactions create social networks, foster confidence, form values, support culture and generate social capital, which constitutes an important part of economic and social life (Poder, 2011, p. 348). This article tries to bring the main recent findings of the authors together. None of these definitions are better than others, but all of them conceptualize the multifaceted aspects of social capital.

The French Sociologist Pierre Bourdieu, ${ }^{2}$ in his book Distinction (1984), defines social capital as the "sum of the resources, actual or virtual, that accrue to an individual or a group by virtue of possessing a durable network of more and less institutionalized relationships of mutual acquaintance and recognition," and as "collectively-owned asset endowing members with credits" (Bourdieu, 1992, p. 119; Bhandari, Yasunobu, 2009, p. 487). Bourdieu believes that the most material types of social capital present themselves in immaterial forms and vice versa. And, under

1 For the first time, he explained the term social capital.

2 French sociologist, anthropologist, philosopher (1930-2002); full title of his work: Distinction: A Social Critique of the Judgement of Taste (in French: La Distinction). The first English translation was done in 1984. 
certain conditions, social capital could be convertible into economic capital and may be even institutionalized (Bourdieu, 1986, p. 243). Bourdieu underlined the significance of institutional relationships of mutual recognition to generate social capital. In addition, Bourdieu claims that the volume of social capital depends on the size of the networks of connection.

James S. Coleman ${ }^{3}$ defines social capital by its functions, describing it as conducive to facilitating certain actions, and examines both economic and non-economic benefits that it generates. Unlike other forms of capital, social capital resides in the structure of the relationships (social structures) between actors, and is not embedded in the actors themselves or physical features of production (Coleman, 1988, S98; Bhandari, Yasunobu, 2009, p. 488). Compared with physical capital, social capital is less tangible and less represented in material form. Coleman argues that the creation of social capital depends on the trustworthiness of the social environment; without a high degree of trustworthiness, there is a lack of social capital and, accordingly, institutions could not exist in such circumstances (Coleman, 1988, S102). Other findings of Coleman include: 1) social relations generate social capital, which is a source of information that facilitates actions; 2) Powerful and effective norms in a community constitute social capital, which leads people to activism for collective interests. For Bourdieu and Coleman, all social relationships, social structures and networks facilitate the creation of social capital which could be maintained and strengthened (ibid.). Social capital is represented in the following forms: obligation and expectation (strong mutual obligations leading to the formation of social capital), civic engagement (interpersonal trust), information (the spread of information is valuable and supportive for social capital), norms (they encourage people to engage in collaborative communal actions), relational authority, social organization and social network (a network's degree of closure is pre-condition for avoiding asymmetric relationships and improving the efficiency of the norms) (Coleman, 1988, S103-108; Keele, 2005, pp. 140-147). As Coleman argues, social capital is created "when the relations among persons change in ways that facilitate action" (Coleman, 1990, p. 304). By comparing different kinds of capital, Coleman differentiates social capital as even less tangible than physical and human capital, because it is embodied in the relationships between people and facilitates productive activities (ibid.). Unlike physical capital, which is typically a private good, social capital is a public good,

3 American sociologist, researcher (1926-1995). 
where all members of the circle benefit. Accordingly, for the purpose of creating, maintaining or destroying social capital, Coleman indicates the importance of the closure of the social networks to keep the actors within the system, for the stability of social structure and the specific ideology as well as regular communication and renewal of social relationships. The significance of trust is also underlined in the work of Philip Keefer and Stephen Knack (2005). As they conclude, trust and trustworthiness have an impact on economic outcomes and development, activate paths to innovation and investment, accumulate higher yields to human capital, and also may improve governmental performance, the level of political participation and the functioning of societies (Knack, Keefer, 1997, p. 1252; Feldman, Assaf, 1999, p. 5; Keefer, Knack, 2005a). Moreover, whenever individuals are close socially, both trust and trustworthiness increase; and when partners are of different races and nationalities, trust and trustworthiness decline (Gleaser et al., 2000, p. 840).

Like Bourdieu and Coleman, Robert Putnam ${ }^{4}$ re-asserts that social capital refers to social organization, such as networks, norms, and trust that supports cooperation within a community (Putnam, 1994, p. 7). When citizens mutually trust each other, they are more likely to act for the common public good; socio-political networks are organized horizontally; civic solidarity, 'civic virtue' and communication increases, and an environment for economic growth and democracy develops. Social capital is self-reinforcing and cumulative, and consequently, "[s]uccessful collaboration in one endeavor builds connections and trust - social assets that facilitate future collaboration in other, unrelated tasks. Social capital is a 'public good,' that is, it is not the private property of those who benefit from it... Social capital typically consists of ties, norms, and trust transferable from one social setting to another" (ibid., p. 10).

The outstanding political scientist Francis Fukuyama emphasizes that all groups embodying social capital have a 'radius of trust' which encompasses people for whom the cooperative norms are operative. Accordingly, "if the social capital of a group produces positive externalities, the 'radius of trust' could be larger than a group itself" (Fukuyama, 2001, p. 8). In line with Alexis De Tocqueville, Fukuyama clarifies the political functions of social capital and explains that a low level of social capital is a reason for political dysfunction and inefficient local governance. Francis Fukuyama uses the concept of trust as a measure of social

\footnotetext{
${ }^{4}$ American political scientist.
} 
capital, which could not be accumulated without the norms of reciprocity and successful civil networks. Thus the level of trust directly defines the prosperity, economic well-being and level of democracy in a given community (Feldman, Assaf, 1999, p. 19). Knack and Keefer (1997) find that a one-standard deviation increase in trust at the national level increases economic growth by more than $1 / 2$ of a standard deviation (Gleaser, Laibson, Sacerdote, 2002, F437). According to Fukuyama, "trust arises when a community shares a set of moral values in such a way as to create expectations of regular and honest behavior" (Feldman, Assaf, 1999, p. 19).

For sociologist Nan Lin, the principle behind social capital is simple: "investment in social relations with expected returns.... resources embedded in a social structure which are accessed and/or mobilized in purposive actions" (Lin, 1999, pp. 30-31). Taking into account the role of social capital in social integration and solidarity, Lin regards it as 'relational asset'. Lin rejects the requirement of network closure or density for the utility of social capital and claims that open or closed networks produce better returns in different circumstances (for instance, a denser network will promote the sharing of resources and maintain individual/group resources, while open networks give access to increased resources, which increases opportunities for additional resources) (Lin, 1999, p. 34). Michael Woolcock (1998) joins the definitional debate around social capital and also refers to the norms and networks that facilitate collective action (WorldBank, 2000).

However, there are still a number of definitional disagreements between the approaches of the authors mentioned above. For Bourdieu, social capital is only available for those who make the efforts to build it, while, in accordance with Coleman's approach, social capital is accessible to all in the network without any pre-conditions (Poder, 2011, p. 348). In addition, Lin explains social relations as relationships between individuals, whereas Bourdieu considers that social relations emerge between individuals enrolled in social groups that are products of history (ibid.). In brief, we could differentiate two main schools of thought in the literature on social capital. One (like Bourdieu, Burt, Portes, Landolt, etc.) refers to the resources that individuals can get by means of relationships; they are social and only accessible through and by relationships. The second approach (Loury, Coleman, Putnam, etc.) to social capital is directed at informal networks, formal civic organizations and underlines that it lies in the relationships, and leads public officials and citizens to find common solutions. Regarding the levels of social capital, Bourdieu (1986), Burt 
(1992) and Nan Lin (2001) define social capital at the individual level; Coleman $(1988,1990)$ and Putnam (1993) refer to the community (meso) and societal levels respectively (Sato, 2013, p. 2). A working group in the World Bank, named Social Capital Initiative, adopts the definition of Coleman and Putnam and reports on social capital at the local level (ibid.). Moreover, the functional conceptualization of social capital is the most widely accepted and influential approach in political science, mostly developed by Coleman and Putnam. Their logic underlines that individuals do not stand alone; they accumulate their individual interests and interlink rational choices and social interaction (Poder, 2011, p. 343). This approach strives to identify social relationships which encourage cooperation. Both Coleman and Putnam presume trust and norms as significant outcomes of social networks, which enables collective action in return. Another understanding of social capital is the network-based approach, developed by Pierre Bourdieu. The main criticism of the network-based approach is directed at its narrowness, which leaves the key explicable dimensions of collective action out (Tirmizi, 2005, p. 37). Because of this, this approach is regarded as parsimonious and modest.

\section{Positive impacts of social capital}

Many positive effects of social capital have been explored in different fields, such as political performance (Putnam), educational attainment (Coleman), healthcare, economic growth/poverty reduction (Narayan, 2000), crime reduction (Putnam, 1994), community development (Uphoff, Wijayaratna, 2000), post-disaster community recovery (ChamleeWright, Storr, 2011) and many more. More concretely, socio-cultural factors, such as trust, conventions, shared values, face-to-face contact, norms, etc., provide the supportive framework for widespread dynamic economic action (Evans, Syrett, 2007, p. 55). At the local level, extensive social co-operation, high value of sharing and mutual support have resulted in the effective allocation of local concerns. ${ }^{5}$ In the neighbor-

${ }^{5}$ For instance, the case of irrigation system construction in Nepal, empirically studied by Ostrom (2000). Anthropologist Alan Fisken explains the benefits of the reciprocal social interaction using the case of ethnic group Mossi in Burkina Faso. Because of having a sense of common identity, high degree of mutual solidarity and crisis-support, the Mossi ethnic group has created favorable conditions for household welfare (Grootaert, Oh, Swamy, 1999, p. 3). 
hood context, social capital is associated with shared norms, reciprocity, daily interactions, trust and collective actions of residents (whether they are long-term/short-term stayers or newcomers). As Middleton and colleagues state: "social capital is seen as the foundation on which social stability and a community's ability to help itself are built; and its absence is thought to be a key factor in neighbourhood decline" (Kleinhans, Priemus, Engbersen, 2007, p. 1069). Putnam comments that a neighborhood with high levels of social capital will be better for a safe, clean and friendlier life (Putnam, 2000, p. 332). A basic level of trust is essential to create a favorable social climate in the neighborhood for positive interactions. Shared social norms and reciprocity make residents' behavior predictable and encourage them to invest in neighborhood-based social capital, partly to protect their investments. Researchers have identified a strong correlation between social capital and community resilience (Chamlee-Wright, Storr, 2011, p. 266).

Other significant positive effects could be empirically observed between social capital and democracy. ${ }^{6}$ Theorists have argued that if a country has a dynamic associational life, it supports democracy. Where citizens frequently interact and trust each other, their relationships enforce democratization and provide the ground for citizens to take part in politics (Paxton, 2002, p. 254-56).

Regarding the debates on whether social capital is created intentionally or unintentionally, most scholars describe social capital as a result of unintentional activities, but Burt (1992) and Lin (2001) argue that actors intentionally strive to create social networks and to improve their status. Social capital is frequently a by-product of the direct (for instance, state support for educational programs) and indirect (for example, providing public safety) involvement of governments. When the functions are not distributed/delegated (no decentralization) and the state performs the activities that should be carried out by CSOs or the private sector, it affects the formation of social capital in a negative way. Also, social enterprises are seen as effective creators of social capital, because of the building up of the social services which require close relationships and commitment of partners, volunteers and other actors in a local cultural context (Evans, Syrett, 2007, p. 60).

${ }^{6}$ Some quantitative studies are mainly focused on the concepts such as civic culture and say little on the direct measurement of associational life and democracy (Paxton, 2002). 


\section{Variations of social capital}

Social capital takes many forms. The most common types of social capital include: structural and cognitive; bridging, bonding, linking; weak and strong; horizontal and vertical; formal and informal, transnational and 'politically relevant' (Bhandari, Yasunobu, 2009, pp. 497-500).

Uphoff (2000) delineates two interrelated types of social capital: structural and cognitive. As he underlines, these two types of social capital produce mutually beneficial collective behavior. The structural category is related to different forms of social organization (roles, rules, precedents, procedures and networks) that reciprocally enhance actions (Li, Ye, 2014; Evans, Syrett, 2007). Also, the cognitive category is associated with mental processes and ideas, reinforced by culture, ideology, norms, values, beliefs and attitudes that predispose people to collaborate (Uphoff, 2000, p. 219). Regardless of the fact that structural social capital is observable and extrinsic and cognitive capital is not, they are both interlinked and interdependent in practice (ibid.). Moreover, Uphoff differentiates various degrees of social capital: minimum social capital (no interest in others' welfare, seeking self-interest maximization at others' expense), elementary social capital (interest in own welfare and cooperation serves one's own advantage), substantial social capital (cooperation based on the common commitments and benefits to others), and maximum social capital (concern for the public good). He regards "mixed motive"-based social capital as the most beneficial, productive and sustainable, with a positivesum and long-lasting outcome (ibid., p. 230).

Relational social capital is linked to the personal relationships developed throughout the history of interactions between individuals. Bridging social capital includes the actual and potential resources embedded within the network of 'weak ties' (extensive and diverse low-density networks of acquaintances) and facilitates the broad identities and reciprocity among members. It refers to the relationships among people and groups who are not alike. Bonding social capital includes the actual and potential resources embedded within the network of 'strong ties' (friendships, classmates or colleagues), typically characterized by trust, intimacy and reciprocity (Levy, Peiperl, Bouquet 2013, pp. 322-324). Linking social capital unifies people with different backgrounds, experiences, locations and status. It connects communities with diverse agencies. Linking connects people to different political resources and economic institutions, and access to linking social capital is apparently central for well-being 
(Woolcock et al., 2004, p. 4). Transnational social capital refers to the interaction of the cross-border networks, interlinking people and organizations, and both bridging and bonding social capital are integral elements of this (Yasin, Quoquab, Kamarudin, 2016, p. 56). Strong or weak social capital is related to well-built or fragile ties within the community. The horizontal type portrays the links between people with similar status, whereas vertical social capital clusters people belonging to different levels in the hierarchy together. Formal social capital involves participation in formally-constituted organizations (approach provided by Putnam) and informal social capital lies in the informal bonds connecting people (approach provided by Coleman and Bourdieu) (Pichler, Wallace, 2007, p. 424). Forms of social capital diverge widely across Europe. In the Nordic countries, participation in the formal organizations is well-developed (formal social capital), while the predominance of informal social capital has been identified in the Eastern and Central Europe (ibid., p. 426). Regarding the formal and informal capital, Pichler \& Wallace formulate two propositions: 1) complementarity of formal and informal capital - when there are strong forms of participation in civil society, strong forms of social bonding and social support are also identified; and 2) substitution of formal social capital by informal social capital - when the participation in formal civil institutions is weak, stronger forms of informal networks and social support are expected.

The politically relevant social capital increases the likelihood that a citizen will be politically engaged and is generated through recurrent networks of social relations, as a consequence of political expertise and regular communication. The presence of politically relevant social capital guarantees "the achievement of certain ends that in its absence would not be possible" (La Due Lake, Huckfeldt, 1998, p. 569). Also, the results of collectively solved problems are frequently observed and touched on in daily life. Communities with high levels of social capital have all-embracing civic networks and trusting attitudes, which consequently expedites economic advance, education, confidence in institutions, etc. (Keele, 2005, p. 139).

Social capital is a measure of social cohesion. Social integration in Europe is marked as a result of transnational relationships between people. In this case, border regions play a key role. Transnationality refers to the crossing of bordering regions and creates the transnational social capital. Transnational social capital is a combination of actual and potential resources embedded within cross-border networks. This type of capital affects collective identity formation beyond the nation-state. According to 
Delhey, social integration in border areas mostly includes the transnational pair-wise connections, which are realized on the micro level, and depends on the coherence, trust, solidarity and attitude of the regional neighbors. Ripple et. al in Crossing the Frontier, underline that transnational social capital crosses the national borders and its emergence is fully related to the social and territorial opening of borders. In the cross-border context, bonding social capital contributes to the safety and well-being of individuals in alien locations, while bridging social capital facilitates access to the resources, and therefore they construct transnational social capital.

\section{Accumulation and measurement of social capital}

The distinguishing characteristic of social capital is how it is accumulated. It is well-known that the creation and activation of social capital requires at least two people, and is both an input and output of the collective actions. As an input, social capital makes decision-making easy and predicts behavior among communities, reduces uncertainty and ambiguity between community members, provides resources, supports coordination and communication and facilitates quicker responses to any failure in the community (Tirmizi, 2005, pp. 23-24). As an output, social capital links community members together, exchanges information and creates more opportunities for stability, empowerment and development.

This raises debates as to how social capital could be measured. Putnam remarks: "since trust is so central to the theory of social capital, it would be desirable to have strong behavioral indicators of trends in social trust or misanthropy. I have discovered some such behavioral measures" (Gleaser et al., 2000, p. 812). Others refer to simpler methods of measurement, such as reported social trust. Gleaser and colleagues measure trust and trustworthiness by conducting trust experiments with monetary rewards ('Trust Game' and 'Envelope Drop'7). More concretely, they

7 The experiment 'Trust Game' was carried out among the undergraduates of Harvard University. Students were paired up and met. Then they were separated, and one of the pair sent money (from $\$ 0$ to 15) to his/her partner (receiver). The researchers doubled each dollar sent. The receiver could return money back to the sender. The logic of this game is similar to the reproduction of a public good. Also, the amount of money sent by a sender is a natural measure of trust. The sender trusts the 'recipient' to return a fair share of the amount he/she receives. The amount of money returned is a measure of trustworthiness. The logic of the second experiment, 'Envelope Drop', is that the en- 
measure subjects' attitudes, background characteristics (level of status/ organization membership) and social connectedness, individual and situational correlations with trust (Gleaser et al., 2000).

The empirical studies over the social reveal that it could be analyzed at both individual and collective levels. Referring to the geographical dimension, it could be studied at micro, meso and macro levels.

The analysis of social capital at the micro-level is developed by Putnam who described the associational life in Italy; Coleman focuses on the broader (meso) interpretation of social capital - relations among groups rather than individuals; and, the macro level of analysis by Douglass North and Mancur Olson outlines the influence of formalized institutions and structures over the patterns of social capital formation (see the diagram below) (Grootaert, Thierry van Bastelaer, 2001, p. 20).

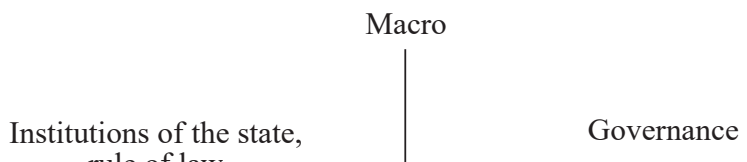
rule of law

Structural

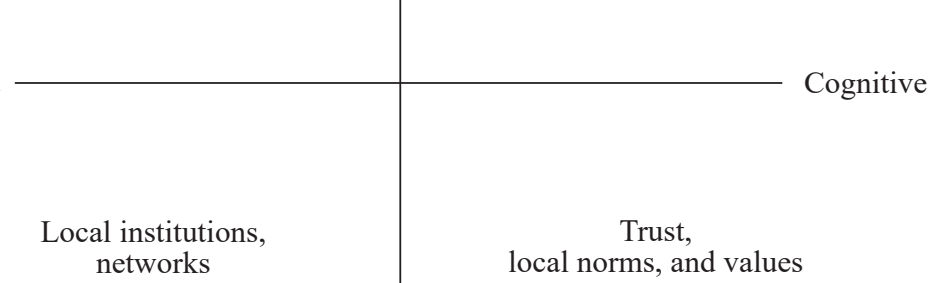

In Seferiadis et al. (2015), Foley and Edwards remark that social resources could be organized at different levels of networks: dyads and informal networks, voluntary or faith-based associations, communities, cities, and national- or transnational-level social movements. As Rothstein (2003) comments, the theory of social capital facilitates the "unusual combination of macro-sociological structures with micro-level mechanisms" (Seferivelope with address and $\$ 10$ was intentionally dropped by a researcher. The experiment is trusting anonymous strangers to send the lost envelope (Gleaser et al., 2000). 
adis et al., 2015, p. 173). In the classification of levels where social capital could be generated, Seferiadis and colleagues empirically explain how the development initiatives (micro-credit or fisheries management in Bangladesh, collective wash stations in Rwanda) at the micro level produce social capital. Firstly, they argue that the formation of social capital at the grassroots level is based on the following mechanisms: it primarily involves the facilitation of physical social interaction; secondly, creation of structural platforms ${ }^{8}$ supports production of social capital by developing shared norms and a sense of belonging; thirdly, civic literacy, such as learning skills for successful cooperative actions, plays a crucial role in engaging in collaboration and, fourthly, an ethos of mutuality provides better management of common goals and strengthens social capital (ibid., pp. 178-181). Therefore, investing in these mechanisms triggers the production of different combinations of social capital, largely dependent on the micro-level context. The formation of social capital is illustrated below.

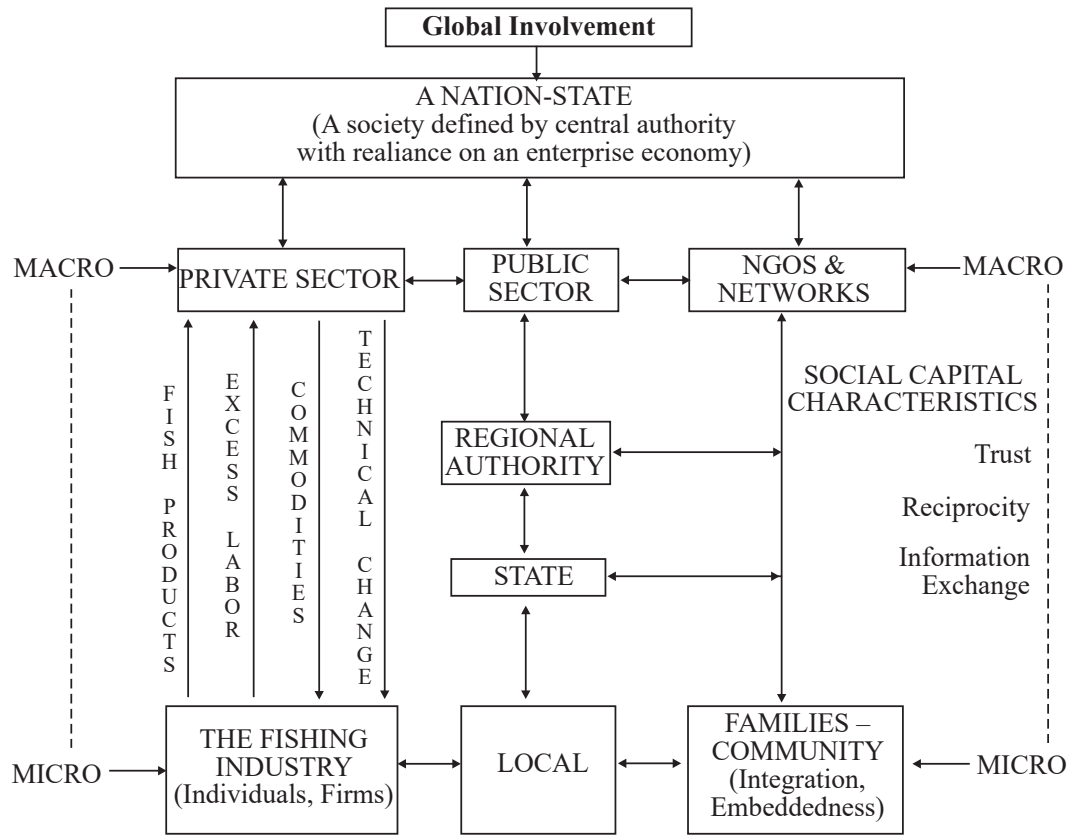

Figure 1. Social Capital in a Nation State: Micro to Macro Conditions Source: Castle, 2002, p. 341.

${ }^{8}$ Which make meetings and interactions easier. 
'Bottom-up' development initiatives ('grassroots' initiatives, micro level) function within the social relationships between neighborhood communities and people with a common religion, and ethnic or familial ties. 'Topdown' development initiatives (state-society relations, macro level) imply the articulation of the needs, interests and resources of both sides. Uphoff underlines that 'top-down' efforts are needed to sustain and institutionalize 'bottom-up' development (Woolcock, 1998, p. 165; Woolcock et al., 2004, p. 3). Woolcock argues that diversity of developmental outcomes and sustained development comes from the interaction of both realms, which is not easy to achieve. Peter Evans (1996) argues that 'state-society synergy' (an active government and mobilized community) could mutually reinforce the development. The structure of synergic relations includes a combination of complementarity (mutually supportive actions between public and private sectors) and embeddedness (ties between citizens and public officials). The value of synergic strategies is evident; they can foster social capital, which is a powerful tool for development. Patrick Heller in his paper discusses the case of Kerala (India), and argues that the synergy of state intervention and class mobilization directly resulted in mutually reinforcing interactions, a high level of social development and successful redistributive reforms/ class coordination (Heller, 1997, p. 1066).

\section{Strong linkage between cross-border cooperation and social capital formation}

The above discussion has clarified that social capital requires "an objective network of ties among individuals" and these ties must be trusting, reciprocal and emotionally positive (Paxton, 2002, p. 256). In view of that, cross-border cooperation has knitted historically hostile neighbors together at national, sub-national and local levels in Europe. In the EU, $\mathrm{CBC}$ has become a way of building trust between countries sharing common borders, and an integral part of both the formal and informal integration processes within the Union' ${ }^{9}$ (Grix, 2001, p. 6).

Scholars consider that social capital is relational, embedded in the social relationships. It interlinks communities across borders and, in general, leads

9 Jonathan Grix emphasizes that formal integration is driven by policy-makers to create rules and common institutions, to work with or through them, to regulate, channel, redirect, encourage or to pursue common policies; and, informal integration is a matter of flows and exchanges, networks and interaction. 
to the better relationships between them. $\mathrm{CBC}$ fosters contacts and networks between communities, establishes common border-region identity, and generates social capital and mutual understanding on both sides of the borders.

The literature highlights favorable conditions, such as initial governmental input, local knowledge, common endeavor and effective communication to develop social capital (Mirwaldt, 2009, p. 5). CBC carries all supportive characteristics essential to generating it. More concretely, cooperation across borders implies the input of national, local and EU authorities, and the creation of the Euroregions is a good case. Secondly, the officials of the Euroregions are aware of the local concerns and all efforts contribute to building a trusting atmosphere for common endeavors. Thirdly, all stakeholders from both sides of the borders are involved in improving communication among the cross-border settings.

CBC generates many forms of social capital, which itself is vital to realizing collaborative initiatives on the ground locally. $\mathrm{CBC}$ fits both structural and cognitive categories of social capital. It certainly implies both 'embedded' (intra-community relations) and 'autonomous' (extracommunity links) social ties at the local level of interaction. As a unique phenomenon, $\mathrm{CBC}$ undoubtedly facilitates face-to-face or regular trusting relations between people or within associations (Putnam's logic). On the other hand, $\mathrm{CBC}$ creates CBRs (Euroregions), a structure of social relations in which social capital resides (Coleman's structure-centered approach). $\mathrm{CBC}$ generates assets for communities located on both sides of the border and leads to common commitments to all (substantial social capital). In practice, it unifies people and agencies with diverse backgrounds from either side of borders (linking social capital), refers to the cross-border networks (transnational social capital), and facilitates reciprocal interactions between people with similar characteristics ('bonding' social capital) and people with different identities ('bridging' social capital). Under the condition of $\mathrm{CBC}$, community members are either participants of formally established cross-border regional organizations, governed by specific rules and procedures (formal social capital), or united through informal bonds and networking (informal social capital). Due to the fact that cooperation across borders is based on various common objectives and has a multi-functional nature, it generates the most beneficial and tenable 'mixed-motive based social capital'. The production of social capital encourages people to become more politically sensitive and concerned, and $\mathrm{CBC}$ may also facilitate interaction over political concerns and accelerate participation in traditional political activities. 
The central idea of both the $\mathrm{CBC}$ and SC concepts is social interaction. It is a first step to producing social capital and a fundamental prerequisite to flourishing CBC. And, accordingly, mutual trust is an important variable for positive reciprocity and interaction, as "a society becomes jaded and mistrustful as levels of interpersonal trust decline" (Keele, 2005, p. 151). CBC brings people socially closer together, which raises the level of trust among them. And, Euroregions (EU cross-border regions), as a common cross-border authority, serve to deal with local troubles and increase transnational social capital.

$\mathrm{CBC}$ is a phenomenon which creates channels of social interaction across borders, and therefore it contributes to the mobilization of social capital at the local level. As a continuous process, CBC creates a favorable environment for both material (intensive economic exchange, establishment of local business enterprises, tourism development, job creation, etc.) and immaterial forms (trust, shared values, common identity, reciprocity, confidence in neighbors, predictability) of social capital. Through cooperation across borders, the border community residents get collaboratively involved in civic affairs and create collective goods accessible to all. Therefore, like social capital, we can identify $\mathrm{CBC}$ as a collectively-owned asset.

\section{Conclusion}

To conclude the definitional discussion, all outstanding scholars mentioned have contributed to the explanations of multi-dimensional features, empirical effects, formation and characteristics of social capital. The concept is widely used to describe social phenomena, but there is still inconsistency and little consensus on its use and meaning (Reimer et al., 2008, p. 257). As a multi-sided phenomenon, it encircles social norms, values, trust, networks, relationships, interactions, institutions, and information exchange, active participation that facilitates collective actions, social cohesion and overall development. Any form of social capital, either material or non-material, cognitive or structural, linking, bonding and bridging, transnational, formal or informal, strong or weak, horizontal or vertical, generates profits for mutually beneficial collective action and development (Grootaert, Thierry van Bastelaer, 2001).

In my research, I conceptualize social capital as rooted in social relationships, coordinated with both structural and normative aspects. This research goes beyond the individualistic definition (e.g. Coleman) and 
recognizes social capital as norms and relations embedded in the social structures of communities, which enables them to act collectively and realize desirable objectives.

Social capital emerges as an outcome of everyday mutual interaction, based on shared values and reciprocity, and its 'stock' is strengthened by mutual contact. It is either the result of the networks of connections or embedded in social structures. The communities with a high stock of social capital are safer, cleaner, wealthier, more literate, and more often employed, and community members use resources more efficiently, resolve disputes more competently and promptly respond to members' needs (Woolcock, 1998).

Trust is a principal and crucial component of the social capital concept, which arises from the effective operation of norms. The degree of trust defines the level of social capital. It is fundamental for collective actions to perform community development policies. There is an empirical correlation between trust and group membership, collective behavior, economic growth and so on. On one hand, a high-trust society is better for keeping governments honest and efficient and, on the other hand, a society with strong political institutions strengthens trusting attitudes, and facilitates communities to act (Keefer, Knack, 2005b). The level of trust directly conditions economic prosperity and the degree of democracy in a community. In high-trust environments, transaction costs for education policy, democratic processes or economic productivity are noticeably lower than they are in the low-trust communities (Mirwaldt, 2009).

Social capital is accumulated at different levels and its size depends on the context itself. While some scholars discuss it as a property of communities, others are focused on the individual and relational levels. The spotlight of my research is focused on the production of social capital at the local level.

The successful implementation of $\mathrm{CBC}$ initiatives requires reciprocal collective activities, high levels of trust, and the development of solid cross-border networks and the establishment of common intentional authority. Such a scenario is possible under 'soft' border regimes, because they speed up transnational social interactions and generate many types of social capital (formal, informal, transnational, 'politically relevant,' strong, horizontal and vertical). Social capital operates through transborder relationships, and, accordingly, it reinforces information flows, common identity, mutual recognition, and collective actions and supports social credentials in a given cross-border area. 


\section{Bibliography}

Bhandari H., Yasunobu K. (2009), What Is Social Capital? A Comprehensive Review of the Concept, "Asian Journal of Social Science” 37 (3), pp. 480-510. doi:10.1163/156853109X436847.

Bourdieu P. (1986). The Forms of Capital, in: Handbook of Theory and Research for the Sociology of Education, ed. J. Richardson, Greenwood, New York.

Bourdieu P., Wacquant L. J. D. (1992), An Invitation to Reflexive Sociology, The University of Chigaco Press.

Castle Emery N. (2002), Social Capital- An Interdisciplinary Concept, "Rural Sociology” 67 (3), pp. 331-349, doi:10.1111/j.1549-0831.2002.tb00107.x.

Chamlee-Wright E., Virgil H. S. (2011), Social Capital as Collective Narratives and PostDisaster Community Recovery, "The Sociological Review” 59 (2), pp. 266-82.

Coleman J. S. (1988), Social Capital in the Creation of Human Capital, "American Journal of Sociology" 94, pp. 95-120.

Coleman J. S. (1990), Foundations of Social Theory, The Belknap Press of Harvard University Press, Cambridge-Massachusetts.

Evans M., Stephen Syrett (2007), Generating Social Capital?, "European Urban and Regional Studies" 14 (1), pp. 55-74, doi:10.1177/0969776407072664.

Feldman T. R., Assaf S. (1999), Social Capital: Conceptual Frameworks and Empirical Evidence: An Annotated Bibliography, "Social Capital Iniciative," http:// siteresources.worldbank.org/INTSOCIALCAPITAL/Resources/Social-Capital-Initiative-Working-Paper-Series/SCI-WPS-05.pdf.

Fukuyama F. (2001), Social Capital, Civil Society and Development, "Third World Quarterly” 22 (1), pp. 7-20, doi:10.1080/01436590020022547.

Glaeser E., Laibson D., Sacerdote B. (2002), An Economic Approach to Social Capital, "The Economic Journal" 112, pp. F437-F458, doi:10.2307/798456.

Edward L. Glaeser, David I. Laibson, Jose A. Scheinkman, Christine L. Soutter

Gleaser L. E., Laibson D. I., Scheinkman J. A., Soutter L. C. (2000), Measuring Trust, "The Quarterly Journal of Economics" 115 (3), pp. 811-46, http://links.jstor. org/sici?sici=0033-5533\%2820008\%29115\%3A3\%C811\%3AMT\%3E2.0. $\mathrm{CO} \% 3 \mathrm{~B} 2-\mathrm{P}$.

Grix J. (2001), Towards a Theoretical Approach to the Study of Cross-Border Cooperation, "Perspectives," no. 17, pp. 5-13.

Grootaert C., Oh G.-T., Swamy A. (1999), The Local Level Institutions Study: Social Capital and Development Outcomes in Burkina Faso, "Local Level Institutions, Working Paper, World Bank".

Grootaert C., van Bastelaer T. (2001), Understanding and Measuring Social Capital: A Synthesis of Findings and Recommendations from the Social Capital Initiative, Center for Institutional Reform and the Informal Sector University of Maryland, doi: 10.1227/00006123-197907010-00058.

Hanifan L. J. (1916), The Rural School Community Center, "The Annals of the American Academy of Political and Social Science" 67, pp. 130-38. 
Heller P. (1997), Social Capital as a Product of Class Mobilization and State Intervention: Industrial Workers in Kerala, India, in: State-Society Synergy: Government and Social Capital in Development, ed. P. Evans, University of California, GAIA Research Series, Berkeley, pp. 48-85.

Keefer P., Knack S. (2005a), Social Capital, Social Norms, and the New Institutional Economics, in: Handbook of New Institutional Economics, pp. 701-726. doi: 10.1007/0-387-25092-1_28.

Keefer P., Knack S. (2005b), Social Capital, Social Norms and the New Institutional Economics, in: Handbook of New Institutional Economics, eds. C. Menard, M. M. Shirley, Springer US, Boston, MA, pp. 701-725, doi: 10.1007/0-38725092-1 28.

Keele L. (2005), Macro Measures and Mechanics of Social Capital, "Political Analysis" 13 (2), pp. 139-156. doi: 10.1093/pan/mpi008.

Kleinhans R.,Priemus H., Engbersen G.(2007), Understanding SocialCapitalinRecently Restructured Urban Neighbourhoods: Two Case Studies in Rotterdam, "Urban Studies" 44 (5/6), pp. 1069-1091, doi: 10.1080/00420980701256047.

Knack S., Keefer P. (1997), Does Social Capital Have an Economic Payoff? A Cross-Country Investigation, "Quarterly Journal of Economics" 112 (4), pp. 1251-1288.

La Due L. R., Huckfeldt R. (1998), Social Capital, Social Networks, and Political Participation, "Politcal Psychology" 19 (3), pp. 567-584.

Levy O., Peiperl M., Bouquet C. (2013), Transnational Social Capital: A Conceptualization and Research Instrument, "International Journal of Cross Cultural Management" 13 (3), pp. 319-338, doi: 10.1177/1470595813485940.

Li Y., Ye F. (2014), Social Capital, Information Sharing and Performance. Evidence from China, "International Journal of Operations \& Production Management" 34 (11), pp. 1440-1462, doi: 10.1108/IJOPM-03-2013-0132.

Lin N. (1999), Building a Network Theory of Social Capital, "Connections" 22 (1), pp. 28-51, doi: 10.1108/14691930410550381.

Mirwaldt K. (2009), The Small Projects Fund and Social Capital Formation in the Polish-German Border Region: An Initial Appraisal, "European Policy Research Paper," no. 68, Glasgow.

Ostrom E. (1999), Social Capital: A Fad or a Fundamental Concept?, "Social Capital: A Multifaceted Perspective" 218.

Paxton P. (2002), Social Capital and Democracy: An Interdependent Relationship, "American Sociological Review" 67 (2), pp. 254-277.

Pichler F., Wallace C. (2007), Patterns of Formal and Informal Social Capital in Europe, "European Sociological Review" 23 (4), pp. 423-435, doi: 10.1093/ esr/jcm013.

Poder T. G. (2011), What Is Really Social Capital? A Critical Review, "The American Sociologist" 42 (4), pp. 341-367.

Putnam R. (2000), Bowling Alone: The Collapse and Revival of American Community, Simon\&Schuster Paperbacks, New York, https://books.google.ge/ 
books?id=rd2ibodep7UC\&printsec $=$ frontcover\&source $=$ gbs_ge_summary $\mathrm{r} \& \mathrm{cad}=0 \# \mathrm{v}=$ onepage $\& \mathrm{q} \& \mathrm{f}=$ false.

Putnam R. D. (1994), Social Capital and Public Affairs, "Bulletin of American Academy of Arts and Sciences" 47 (8), pp. 5-19.

Reimer B., Lyons T., Ferguson N., Polanco G. (2008), Social Capital as Social Relations: The Contribution of Normative Structures, "The Sociological Review" 56 (2), pp. 256-274.

Sato Y. (2013), Social Capital, "Sociopedia. ISA," pp. 1-10, doi: 10.1177/ 205684601374.

Seferiadis A. A., Cummings S., Zweekhorst M. B. M., Bunders J. F. G. (2015), Producing Social Capital as a Development Strategy: Implications at the Micro-Level, "Progress in Development Studies" 15 (2), pp. 170-185, doi: $10.1177 / 1464993414565530$.

Tirmizi S. N. A. (2005), The Contribution of Levels of Social Capital to Community Development, Iowa State University.

Uphoff N. (2000), Understanding Social Capital: Learning from the Analysis and Experience of Participation, in: Social Capital. A Multifaceted Perspectiv, eds. P. Dasgupta, I. Seageldin, The International Bank for Reconstruction and Development, Washington DC.

Uphoff N., Wijayaratna C. M. (2000), Demonstrated Benefits from Social Capital: The Productivity of Farmer Organizations in Gal Oya, Sri Lanka, "World Development" 28 (11).

Woolcock M. (1998), Social Capital and Economic Development: Toward a Theoretical Synthesis and Policy Framework, "Theory and Society" 27, pp. 151-208.

Woolcock M., Grootaert C., Narayan D., Nyhan Jones V. (2004), Measuring Social Capital: An Integrated Questionnaire, Washington D.C.

WorldBank (2000), The Place of Social Capital in Understanding Social and Economic Outcomes.

Yasin N. M., Quoquab F., Kamarudin S. (2016), Transnational Social Capital, Business Model Design, and Firm's Growth in the Context of University Spin-off Companies, "International Review of Management and Marketing" 6 (S4), pp. 53-60.

\section{Związek między wspólpracą transgraniczną a kapitałem społecznym: ramy koncepcyjne}

\section{Streszczenie}

Artykuł analizuje dyskusję na temat definicji kapitału społecznego, aby wykazać jego wielostronny charakter. W odniesieniu do relacyjnego charakteru kapitału społecznego, artykuł traktuje go jako wynik współpracy transgranicznej. Podstawą ka- 
pitału społecznego jest interakcja społeczna, a współpraca transgraniczna w równym stopniu ułatwia jak i wzmacnia interakcję ponad granicami państwowymi. Dlatego w niniejszym artykule współpraca transgraniczna traktowana jest jako metoda generowania formalnych/nieformalnych, łączących, wiążących, pomostowych, transnarodowych i innych odmian kapitału społecznego.

Słowa kluczowe: kapitał społeczny, współpraca transgraniczna, otoczenie transgraniczne, interakcja społeczna 
